\title{
Feeding Wild Sunflower (Tithonia Diversifolia Hemsl., A. Gray) to West African Dwarf Goats as a Dry Season Forage Supplement
}

\author{
Odedire J.A*, Oloidi F.F \\ Department of Animal Sciences Obafemi Awolowo University Ile-Ife, Nigeria \\ *Corresponding author: oadeolu1@gmail.com
}

Received October 25, 2014; Revised November 18, 2014; Accepted December 05, 2014

\begin{abstract}
A study was conducted to investigate the nutritional response of West African Dwarf (WAD) goats offered a concentrate diet containing Wild sunflower leaf meal, as a dry season feed supplement. Twenty WAD goats with age range of $5-7$ months, weighing approximately $6.94 \pm 0.37 \mathrm{~kg}$ were randomly allotted to a concentrate diet containing graded levels of Wild sunflower leaf meal (WSLM) at 0, 10, 20 and 30\% levels of inclusion, offered as supplement to a guinea grass basal diet, in a completely randomized design. The experiment, which lasted 16 weeks, measured the nutritional performance indices of the WAD goats such as Feed intake, Weight gain, Digestibility, Nitrogen utilization and Feed conversion ratio. Results obtained indicate no significant difference in the dry matter intake (DMI), weight gain and dry matter digestibility of the goats on the different diets. However, the crude protein digestibility and nitrogen utilization of goats on $0 \%$ and $10 \%$ WSFLM inclusion were higher than those on $20 \%$ and $30 \%$ WSLM diet. It was concluded that wild sunflower leaf meal can serve as a forage supplement to the WAD goats up to $30 \%$ level of inclusion without any deleterious effect.
\end{abstract}

Keywords: digestibility, nitrogen utilization, WAD goat, wild sunflower leaf meal

Cite This Article: Odedire J.A, and Oloidi F.F, "Feeding Wild Sunflower (Tithonia Diversifolia Hemsl., A. Gray) to West African Dwarf Goats as a Dry Season Forage Supplement.” World Journal of Agricultural Research, vol. 2, no. 6 (2014): 280-284. doi: 10.12691/wjar-2-6-6.

\section{Introduction}

The major constraint to ruminant livestock production in the tropics is the availability of cheap and quality feedstuffs, especially in periods of drought or dry season. The increasingly expensive nature of most feed ingredients has resulted in reduced livestock production activities by the ordinary peasant farmers who constituted the majority of the livestock holder, and this has impacted negatively on the available animal protein for human consumption.

Feed alone has been reported to account for $60-80 \%$ of the total cost of any livestock production [1]. Although, grasses abound in the tropics, seasonal changes in their palatability and nutritive values have been a major challenge in ruminant animal production [2]. The desire of most ruminant livestock producers have been towards the search for mostly, cheaper feed ingredients that are readily available for the better part of the tropical season and have no competition with man's dietary demands. This therefore necessitates the search for alternatives to conventional feed resources that have hitherto been regarded as "weeds" due to their poor or low utilization in the livestock feed industry. Such alternative feed resources include Mimosa [3], Vetiver [4], Tephrosia [5] and Tithonia [6]. Although utilization of leaf meals of legumes such as wild sunflower, mimosa, calopo, gliricidia, as source of protein and/ or energy in livestock nutrition have been investigated, most of these studies have been concentrated on monogastric livestock $([3,6,7,8])$.

Wild sunflower (Tithonia diversifolia) is a weed of cultivated crops, wasteland and road sides. It could be cultivated by resource poor farmers who could manipulate planting density to achieve maximum yield [9]. The plant is an early colonizer at the start of rains and is capable of growing late into the dry season when most forages are no longer available due to drought [10]. This plant has some attributes to qualify it as a cheaper substitute to conventional resources. It is abundant in nature, it has limited processing demand and it is not in competitive demand for human consumption [11]. Limited information exists on the effect of wild sunflower meal on the growth, digestibility and nitrogen utilization of WAD goats, hence this study. The aim of this study, therefore, was to determine the effect of feeding a concentrate supplement containing Wild sunflower leaf meal (WSFLM) on the nutritional response of West African Dwarf (WAD) goats.

\section{Materials and Method}

The experiment was carried out at the Sheep and Goat Unit of the Teaching and Research Farm, Obafemi Awolowo University, Ile-Ife. Twenty growing West 
African Dwarf (WAD) goats weighing approximately 6.94 $\pm 0.37 \mathrm{~kg}$, with age range between 5 and 7 months were used for this study. Goats were randomly allotted to four treatments in a completely randomized design, with replicates of five goats per treatment. The goats were housed in an open - sided, well-lighted and adequately ventilated building with concrete floor that had been previously disinfected with Sodium hypochlorite. The concrete floor was covered with $5 \mathrm{~cm}$ layers of wood shavings to absorb urine and for easy removal of faeces. Provision of fresh feed and water were done daily.

\subsection{Processing of Wild Sunflower Leaf Meal}

Wild sunflower leaves were harvested prior to flowering in, and around the Teaching and Research Farm. The harvested leaves were spread on a concrete slab and air dried for seven days and then ground in a laboratory mill with $4.0 \mathrm{~mm}$ sieve size and stored for later use.

\subsection{Experimental Diets}

Four concentrate diets were compounded comprising 0, 10, 20 and 30\% levels of inclusion of wild sunflower leaf meal (WSLM) and fed to the WAD goats (Table 1). The formulated concentrate diets were fed at $40 \%$ of the total feed on offer with the basal ration of guinea grass (Panicum maximum) making up the remaining 60\%. The concentrate diets were offered to the goats first, before they were allowed access to the guinea grass ration. Feeding was done for a period of 112 days. Goats were transferred to metabolism cages with facilities for separate collection of urine and faeces for digestibility trial, towards the end of the growth studies.

\subsection{Digestibility Trial and Nitrogen Utilization}

Digestibility trial was carried out at 14th and 16th week of the experimental period. Faeces and urine were collected daily before the morning feeding. Feed and water were offered ad-libitum for the 14 - day period. Ten percent of faecal samples were taken per day and dried in a forced-draught oven at $70^{\circ} \mathrm{C}$ for 48 hours. At the end of the digestibility trial, daily stored samples of faeces were bulked, thoroughly mixed, ground and sub-sampled for chemical analysis. The volume of urine voided were also measured daily for the 14 - day period. Volatilization of nitrogen from urine was prevented by introducing $0.1 \mathrm{~N}$ of $\mathrm{HCl}$ into the urine container. 10\% of the daily urine voided was taken and stored for later analysis. Data on feed intake, feacal and urine output were collected and used to estimate the digestibility coefficients of nutrients and nitrogen balance according to the method of [12].

\subsection{Measurements}

Each animal was weighed using hanging scale before the commencement of the study and weekly, throughout the experimental period. Experimental diets were fed to the animals for a period of sixteen weeks. Forages and treatment diets were also weighed daily and the feed leftovers were weighed to estimate daily feed intake.

\subsection{Chemical Analysis}

All samples of feeds and faeces were dried in an oven at $70^{\circ} \mathrm{C}$ for 72 hours and sub samples taken and ground using laboratory mortar and pestle. The samples were analyzed for proximate and fibre composition using the method described by AOAC [13]. Crude protein (CP) was analyzed with the aid of a Kjeltec system digester (Tecator Model 1007) and Kjeltec distilling unit (Tecator Model 1002).

\subsection{Statistical Analysis}

Data obtained were statistically analyzed with the General Linear Model of SAS [14] and the Duncan New Multiple Range Test of the same package was used to test for any significant differences among the treatment means.

\section{Results and Discussion}

Table 1 shows the chemical composition of wild sunflower leaf meal (WSLM) and Panicum maximum. The result suggests that the WSLM may serve as an alternative protein feed source for ruminants [15], especially towards the dry season. The crude protein, crude fibre, ether extract and ash values obtained for the wild sunflower leaf in this study were similar to the values reported by Fasuyi et al [16]. Proximate analysis of Panicum maximum used in this study was observed to contain 8.10 CP, 26.12 CF, 8.72 ether extract and 9.80 ash all on g/100 g DM basis, which is indicative of the actively growing phase of the grass before lignification sets in, as evident in its relatively low lignin value (2.84 g/100 g DM). The values of the proximate analysis recorded for Panicum maximum in this study were higher than those obtained by Alasa et al [17]. The difference in values may be as a result of age of the grass and season of harvesting. The values in the present study were similar to the reported values of FAO [18] and Bamikole et al [19] where they reported crude protein value of between 7.20 - 8.25\% CP for Panicum maximum.

Table 1. Chemical composition of wild sunflower leaf meal and Panicum maximum

\begin{tabular}{|c|c|c|}
\hline Parameter (g/100g) & Wild sunflower leaf meal & Panicum maximum \\
\hline Dry matter & 85.37 & 26.26 \\
\hline Crude Protein & 21.14 & 8.10 \\
\hline Crude fibre & 18.90 & 26.21 \\
\hline Ether Extract & 4.00 & 8.72 \\
\hline Ash & 14.14 & 9.80 \\
\hline Nitrogen free extracts & 41.82 & 47.10 \\
\hline $\mathrm{ADF}$ & 43.25 & 49.18 \\
\hline NDF & 63.20 & 69.44 \\
\hline Hemicellulose & 19.95 & 20.26 \\
\hline Lignin & 3.67 & 2.84 \\
\hline
\end{tabular}


Table 2. Gross composition of the experimental diets

\begin{tabular}{|c|c|c|c|c|}
\hline Ingredients & Control & $10 \%$ WSLM & 20\%WSLM & 30\%WSLM \\
\hline WSLM & - & 10.00 & 20.00 & 30.00 \\
\hline Maize & 45.00 & 45.00 & 45.00 & 45.00 \\
\hline Soya bean & 30.00 & 20.00 & 10.00 & - \\
\hline Palm Kernel Cake & 18.00 & 18.00 & 18.00 & 18.00 \\
\hline Groundnut Cake & 4.50 & 4.50 & 4.50 & 4.50 \\
\hline Bone meal & 1.50 & 1.50 & 1.50 & 1.50 \\
\hline Salt & 0.50 & 0.50 & 0.50 & 0.50 \\
\hline Vitamin & 0.50 & 0.50 & 0.50 & 0.50 \\
\hline Total & 100 & 100 & 100 & 100 \\
\hline
\end{tabular}

WSLM: wild sunflower leaf meal inclusion

The gross composition of the experimental diets is shown in Table 2 while the chemical composition of diets is shown in Table 3 . The result of the chemical composition shows that wild sunflower has feed value suitable as livestock feed. All the diets had crude protein values above the 6-8\% CP minimum requirement for ruminants [20]. Blending of roughages and concentrate as a complete diet enhanced feed consumption, live weight gain and feed efficiency in animals [21]. The crude protein levels of the experimental diet was far above the $8 \%$ needed to provide the minimum ammonia levels required for microbial activity in the rumen [22]. Minson [23] reported that low cost concentrate diets with more than 8\% CP could be a good maintenance ration for ruminant animals during dry season, and as such wild sunflower leaf meal could be useful as dry season feed.

Table 3. Chemical composition of diets fed to the experimental goats

\begin{tabular}{|c|c|c|c|c|}
\hline Parameter (g/100g) & Control & $10 \% W S L M$ & 20\%WSLM & 30\%WSLM \\
\hline Dry matter & 90.23 & 91.04 & 91.67 & 91.70 \\
\hline Ash & 8.43 & 7.59 & 8.76 & 8.17 \\
\hline Crude Protein & 17.20 & 15.60 & 15.50 & 15.46 \\
\hline Ether extract & 8.19 & 7.97 & 7.37 & 7.19 \\
\hline Crude fibre & 14.50 & 14.40 & 14.30 & 14.28 \\
\hline Nitrogen free extract & 51.68 & 54.44 & 54.07 & 54.90 \\
\hline Organic matter & 91.57 & 92.41 & 91.24 & 91.83 \\
\hline
\end{tabular}

Control: Concentrate diet without wild sunflower leaf meal

WSLM: wild sunflower leaf meal inclusion

Table 4. Mean nutrient intakes (g/day) by WAD goats fed experimental diets

\begin{tabular}{|c|c|c|c|c|c|c|}
\hline Intake (g/day) & Control & 10\%WSLM & 20\%WSLM & $30 \% W S L M$ & SEM* & $\mathrm{P}$ value \\
\hline \multicolumn{7}{|c|}{ Dry matter } \\
\hline Concentrate & 208 & 208 & 206 & 205 & 3.59 & 0.9233 \\
\hline Panicum maximum & 103.5 & 102.5 & 100.4 & 100.2 & 1.26 & 0.2340 \\
\hline Total & 311.5 & 310.5 & 306.4 & 305.2 & 3.87 & 0.6949 \\
\hline \multicolumn{7}{|c|}{ Crude protein } \\
\hline Concentrate & $35.75^{\mathrm{a}}$ & $32.45^{\mathrm{b}}$ & $31.93^{b}$ & $31.69^{b}$ & 0.38 & 0.0001 \\
\hline Panicum maximum & 8.36 & 8.30 & 8.13 & 8.12 & 1.10 & 0.0622 \\
\hline Total & $44.11^{\mathrm{a}}$ & $40.75^{\mathrm{b}}$ & $40.06^{\mathrm{b}}$ & 39.81 & 1.01 & 0.0001 \\
\hline \multicolumn{7}{|c|}{ Crude fibre } \\
\hline Concentrate & 30.16 & 29.95 & 29.46 & 29.27 & 0.95 & 0.9402 \\
\hline Panicum maximum & 27.04 & 26.87 & 26.74 & 26.28 & 0.36 & 0.9705 \\
\hline Total & 57.20 & 56.82 & 56.10 & 55.55 & 0.74 & 0.9568 \\
\hline \multicolumn{7}{|l|}{ Ash } \\
\hline Concentrate & 18.04 & 17.53 & 16.75 & 15.79 & 0.30 & 0.1829 \\
\hline Panicum maximum & 10.11 & 10.05 & 9.84 & 9.81 & 0.12 & 0.1754 \\
\hline Total & 28.15 & 28.18 & 26.59 & 25.60 & 0.37 & 0.0665 \\
\hline
\end{tabular}

Control: Concentrate diet without wild sunflower leaf meal;

WSLM: wild sunflower leaf meal inclusion; *: Standard error of mean

Table 4 shows the mean nutrient intake (g/day) of digestibility of the feed. The slight reduction in feed intake WAD goats fed the experimental diets. The intakes of Panicum maximum forage by the goats were similar across the treatments. Similarly, their total mean daily dry matter intake (DMI g/day) were also similar across the different diets but the values obtained in this study were lower than those reported by Ahamefule and Elendu [24] where intake ranged between 357 g/day and 456 g/day for West African Dwarf (WAD) goats fed cassava leaf-maize offal based diets. The mean total daily Crude Protein Intake (CPI g/day) of goats fed Control diet was higher than those on concentrates with WSLM inclusion. The CP intake ranged from $31.69 \%$ to $35.75 \%$ CP for goats on $30 \%$ WSLM and control diet respectively. This could be attributed to reduced palatability with increasing WSLM content as Mattewman [25] observed that animal's feed intake was greatly affected by the palatability and with increasing level of WSLM in the diet might be due to the bitter taste associated with saponin which was quite abundant in the wild sunflower leaf [26]. Notwithstanding its effect on feed intake, feedstuffs containing saponin have been reported to be capable of reducing methane production [27], which makes the diet containing WSLM a good option in the current phenomenon of climate change. Meanwhile, the levels of saponin Wild sunflower as reported by [10] are within safe limits for ruminant consumption [26]. The mean total crude fibre intake, ether extract intake, organic matter intake and ash intake were not different across the diets.

Table 5 shows the apparent nutrient digestibility of the experimental diets by WAD goats. The nutrient digestibility values of the goats were similar across treatments except for crude protein where the goats on 
$10 \%$ WSLM and the control diet had a better performance (68.11\% and $68.53 \%$ respectively) than those on $20 \%$ and $30 \%$ WSLM diets (62.62\% and $57.97 \%$ respectively). The results obtained in this study was similar to the report of Ngi et al [28] who obtained a range of $54.01-64.49 \%$ CP digestibility for Maradi $\times$ West African Dwarf cross bred goats fed mixtures of dried cassava leaf meal and maize offal, as dietary supplements to rice straw. However, the values obtained for the crude fibre were lower than that reported by Arigbede [29].

\begin{tabular}{|c|c|c|c|c|c|c|}
\hline Parameter & Control & $10 \%$ WSLM & $20 \%$ WSLM & $30 \%$ WSLM & SEM* & P value \\
\hline Dry matter & 71.24 & 70.57 & 70.66 & 70.98 & 2.42 & 0.7935 \\
\hline Crude protein & $68.53^{\mathrm{a}}$ & $68.11^{\mathrm{a}}$ & $62.62^{\mathrm{b}}$ & $57.97^{\mathrm{b}}$ & 1.75 & 0.0164 \\
\hline Crude fibre & 62.84 & 62.04 & 61.99 & 61.53 & 1.75 & 0.5706 \\
\hline Ether extract & 69.81 & 67.37 & 65.41 & 64.62 & 3.21 & 0.1616 \\
\hline Ash & 71.25 & 68.99 & 70.74 & 69.86 & 1.93 & 0.7740 \\
\hline
\end{tabular}

WSLM: wild sunflower leaf meal inclusion

*:Standard error of mean

Table 6. Mean nitrogen utilization of WAD goats fed experimental diets

\begin{tabular}{|c|c|c|c|c|c|c|}
\hline Parameter (g/day) & Control & $10 \%$ WSLM & $20 \%$ WSLM & $30 \%$ WSLM & SEM* & $\mathrm{P}$ \\
\hline Nitrogen intake & $7.59^{\mathrm{a}}$ & $6.84^{\mathrm{a}}$ & $5.83^{b}$ & $5.76^{b}$ & 0.03 & $0.0210 * *$ \\
\hline Faecal nitrogen & 2.39 & 2.18 & 2.16 & 2.42 & 0.39 & 0.6340 \\
\hline Urinary nitrogen & $1.10^{\mathrm{a}}$ & $1.01^{\mathrm{a}}$ & $0.66^{\mathrm{b}}$ & $0.36^{\mathrm{c}}$ & 0.04 & $0.0012^{* * *}$ \\
\hline Nitrogen balance & $4.10^{\mathrm{a}}$ & $3.65^{\mathrm{a}}$ & $3.01^{\mathrm{b}}$ & $2.98^{\mathrm{b}}$ & 0.37 & $0.0032 * * *$ \\
\hline Nitrogen retention (\%) & $54.02^{\mathrm{a}}$ & $53.36^{\mathrm{a}}$ & $51.62^{b}$ & $51.74^{\mathrm{b}}$ & 2.72 & $0.0223 * *$ \\
\hline
\end{tabular}

a, b, c, : Means within row with different superscript are significantly different $* * *(\mathrm{P}<0.01) ; * *(\mathrm{P}<0.05)$

WSLM: wild sunflower leaf meal inclusion

*: Standard error of mean

The results for nitrogen utilization of the goats fed the experimental diets. The initial weight of the animals experimental diets are presented in Table 6. Faecal nitrogen of the animals was similar, with a range of $2.16-$ $2.42 \mathrm{~g} /$ day (in 20\% WSLM and 30\% WSLM respectively). Urine nitrogen was least in goats fed 30\% WSLM $(0.36$ $\mathrm{ml} /$ day) and highest ( $1.10 \mathrm{ml} /$ day) in goats fed the control, although the values recorded for those on 10\% WSLM and control are similar. On the overall, Nitrogen retention was better in animals on 10\% WSLM and Control diet with values of 53.36 and $54.02 \%$ respectively. The reason for the reduced Nitrogen retention in goats on 20\% WSLM and 30\% WSLM can be attributed to the antinutritive components of Wild sunflower [10], as Nitrogen retention decreases with increasing level of inclusion of WSLM. Notwithstanding the variation in the utilization, all the diets indicated protein values that are in excess of the $6-8 \%$ requirement for ruminant animals [20].

Table 7 shows the performance characteristics of the WAD goats fed the experimental diets. Values for all the parameters measured were similar. Total feed intakes of the animals were similar, ranging from 305.2 - 311.5 $\mathrm{g} /$ day, an indication that the goats were well adjusted to was well balanced at the start of the experiment, resulting in a mean value of $6.94 \pm 0.37 \mathrm{~kg}$ across the treatments. The average weight gain and total weight gains of the WAD goats on the different diets were similar ranging from $26.12 \mathrm{~g} /$ day to $31.73 \mathrm{~g} /$ day and $2.56 \mathrm{~kg}$ to $3.11 \mathrm{~kg}$ respectively. The daily weight gains in this experiment compared well with the results of Ajayi et al [30] who obtained 23.81 - 46.64 g/day for WAD goats fed Mangifera indica, Ficus thionningii and Gliricidia sepium foliages when fed as concentrates supplements to basal diet of guinea grass (Panicum maximum). Ngi et al [28] reported a daily weight gain of $18.6 \mathrm{~g}-20.89 \mathrm{~g} /$ day for Maradi $\times$ West African Dwarf cross bred goats fed mixtures of dried cassava leaf meal and maize offal as dietary supplements to rice straw ad libitum. The values obtained for weight gain in this study were however lower than that reported by Oni et al [31] who obtained a daily gain of 33.8 - 52.9 g/day for West African Dwarf goats fed different levels of dried cassava leaves (Manihot esculenta)- based concentrates with Panicum maximum.

Table 7. Performance characteristics of WAD goats fed the experimental diets

\begin{tabular}{|c|c|c|c|c|c|c|}
\hline Parameter & Control & $10 \%$ WSLM & $20 \%$ WSLM & 30\% WSLM & SEM & PROB \\
\hline \multicolumn{7}{|l|}{ Intake (g/day) } \\
\hline Concentrate & 208.00 & 208.00 & 206.00 & 205.00 & 3.59 & 0.9233 \\
\hline P. maximum & 103.50 & 102.50 & 100.20 & 100.20 & 1.26 & 0.2340 \\
\hline Total Feed Intake (g/day) & 311.50 & 310.50 & 306.20 & 305.20 & 3.87 & 0.6949 \\
\hline Initial weight (kg) & 6.94 & 6.94 & 6.94 & 6.94 & 1.06 & 1.0000 \\
\hline Final weight (kg) & 9.65 & 10.05 & 9.60 & 9.50 & 1.53 & 0.9933 \\
\hline Total weight gain (kg) & 2.71 & 3.11 & 2.66 & 2.56 & 0.02 & 0.1403 \\
\hline Average daily gain (g) & 27.65 & 31.73 & 27.14 & 26.12 & 5.86 & 0.9145 \\
\hline Feed conversion ratio & 11.27 & 9.78 & 11.28 & 11.68 & 0.57 & 0.2322 \\
\hline
\end{tabular}

WSLM: wild sunflower leaf meal inclusion

\section{Conclusion}

It can be concluded that wild sunflower possesses adequate nutritive value as to support good growth of West African Dwarf goats, especially during the period of drought and the forage can effectively serve as alternative feed ingredient in the WAD goat's diet with inclusion level of up to $30 \%$ without any deleterious effect.

\section{Statement of Competing Interests}

The authors have no competing interests. 


\section{References}

[1] Agbede, J.O. and Aletor, V.A. (2003). Evaluation of fishmeal replaced with leaf protein concentrate in diets of broiler chicks. Effects on performance, muscle growth, haematology and serum metabolism. International Journal of Poultry Science 2: 14-19.

[2] Alokan, J. A. (1998). Performance of Yankasa Sheep fed Banana (Musa sapientum) foliage and elephant grass. In: Proceedings of the Silver Anniversary Conference of the Nigerian Society for Animal Production (NSAP), Gateway Hotel, Abeokuta, Nigeria. March 21-26, 1998: 51-52.

[3] Nworgu, F.C. and Fapohunda, J.B. (2002). Performance of broiler chicks fed mimosa (Mimosa invisa) leaf meal supplements. In: Proceedings 28th Annual Conference, Nigeria Society for Animal Production. 128-131.

[4] Panichpol, V., Waipanya, S., Siriwongse, M. and Srichoo, C. (1996). Analysis of chemical composition of Vetiveria zizanioides Nash for using as feed stuff. In: Abstracts of papers presented at ICV-3, Chiang Rai, 4-8 Feb. 96, pp. 141.

[5] Odedire, J.A. and Babayemi, O.J. (2008). Comparative studies on the yield and chemical composition of Panicum maximum and Andropogon gayanus as influenced by Tephrosia candida and Leucaena leucocephala. Livestock Research for Rural Development 20 http://www.cipav.org.co/lrrd//rrd20/2/oded20027.htm.

[6] Odunsi, A.A., Farinu, G.O. and Akinola, J.O. (1996). Influence of dietary wild sunflower (Tithonia diversifolia Helms A.Gray) leaf meal on layers performance and egg quality Nigerian Journal of Animal Production 25: 28-32.

[7] Asongwed, A.A., Abakan, O. and Vail, E. (2003). Intake and digestibility of Calapogonium mucunoides based diet fed to Draft Donkeys during the dry season. Revue d'elevage et de medecine veterinaire des pays tropicaux 56, 205-210.

[8] Ige, A.O., Odunsi, A.A., Akinlade, J.A. and Ojedapo, L.O. (2006). Gliricidia leafmeal in layer's diet: effect on performance, nutrient digestibility and economy production. Journal of Animal Veterinary Advances 5 (6): 483-486.

[9] Akinola, J. O., Farinu, G.O. and Odunsi, A.A. (1999). Seed treatment methods and duration effects on germination of wild sunflower. Experimental Agriculture 36: 63-69.

[10] Odedire, J. A. and Oloidi, F.F. (2011). Processing Wild sunflower (Tithonia diversifolia) leaves as forage supplement in ruminant diet: Effect of air drying method on anti-nutritive components. In: SAADC 2011. Strategies and challenges for sustainable animal agriculture-crop systems. Volume III: Full papers. Proceedings of the $3^{\text {rd }}$ International Conference on Sustainable Animal Agriculture for Developing countries. Nakhon Ratchasima, Thailand. 26-29 July, pp 312-316.

[11] Odunsi, A.A. and Farinu, G.O. (1997). Assessment of Nigerian mango (Magnifera indica) seed kernel as a partial replacement for maize in finishing broiler diets. Indian Journal of Animal Science 67: 605-607.

[12] McDonald, P., Edwards, R.A., Greenhalgh, J.F.D. and Morgan, C.A. (1995). Animal Nutrition. Addison Wesley Longman, Inc., U.K., ISE reprint, 1999. 607 pp.

[13] AOAC (1990). Association of Official Analytical Chemist. Official methods of analysis, $15^{\text {th }}$ ed. Washington D. C. United States of America.

[14] SAS (2008). Stastical Analysis Software. User's Guide Statistics, SAS Inc. Cary., North Carolina, 2008 edition.

[15] Onwuka, C.F.I. (1980). The chemical composition of in vitro organic matter digestibility of some browse. plants in Nigeria. M.Sc. Thesis, University of Ibadan, Department of Animal Science, Ibadan, Nigeria.

[16] Fasuyi, A.O., Dairo, F.A.S. and Ibitayo, F.J. (2010). Ensiling wild sunflower (Tithonia diversifolia) leaves with sugar cane molasses.
Livestock Research for Rural Development. http://www.lrrd.org/lrrd22/3/fasu22042.htm

[17] Alasa, M.C., Akinsola, S.O. and Babayemi, O. J. (2010). Chemical composition and in vitro gas production of Panicum maximum intercropped with two cultivars of Lalab purpureus. In: Proceedings of 35th Annual Conference of Nigerian Society for Animal Production (NSAP), University of Ibadan, Nigeria. March 14-17, 2010. Pp. 587-590.

[18] FAO (2003). Food and Agriculture Organisation of the United Nations. Panicum maximum, guinea grass, colonial grass, Tanganyika http://www.fao.org/ag/aga/agap/frg/AFRIS/DATA/118.htm

[19] Bamikole, M.A., Ikhatua, U.J., Arigbede, O.M., Babayemi, O.J. and Etela, I. (2004). An Evaluation of the acceptability as forage of some nutritive and anti-nutritive components and of the dry matter degradation profiles of five species of Ficus. Tropical Animal Health and Production 36: 157-167.

[20] NRC (1985). Nutrient Requirements of Domestic Animals. Nutrient Requirements of Sheep. National Academy Press. Washington, D.C., USA.

[21] Reddy, G.V.N. and Reddy, M.R. (1999). Effect of feeding extruded complete diet containing maize cobs in Ongole bull calves. Indian Journal of Animal Nutrition 16: 210-214.

[22] Norton, B.W. (1994). Anti-nutritive and toxic factors in forage tree legumes. In: Gutteridge, R.C. and H.M. Shelton (editors). Forage tree legumes in tropical agriculture. CAB International. pp. 202-215.

[23] Minson, D.J. (1990). Forage in ruminant nutrition. Academic Press, San Diego, 483 pp.

[24] Ahamefule, F.O. and Elendu, C. (2010). Intake and Digestibility of West African Dwarf Bucks Fed Cassava Leaf-Maize Offal Based Diets. Journal of Animal and Veterinary Advances 9: 535539.

[25] Matthewman, R.W. (1977). A survey of Small ruminant production at the village level in the derived savannah and lowland forest zones of South-west Nigeria. Agriculture Extension Service Research Bulletin No. 1 pp 1-15.

[26] Njidda, A.A., Ikhimioye, B.F., Muhammad, M. and Amaza, I.B. (2010). Chemical composition, fibre fraction and anti-nutritive substances of selected semi-arid browse. In: Proceedings of $35^{\text {th }}$ Annual Conference of Nigerian Society for Animal Production (NSAP), University of Ibadan, Nigeria March 14-17, 2010. pp. 477-480. Nigeria.

[27] Babayemi, O.J., Demeyer, D. and Fievez, V. (2004). Nutritive value of qualitative assessment of secondary compound in seeds of eight tropical browse, shrub and pulse legumes. Communications in Agricultural and Applied Biological Sciences, Ghent University. 69 (1): 103-110.

[28] Ngi, J., Ayoade, J.A. and Oluremi, O.I.A. (2006). Evaluation of dried cassava leaf meal and maize offal as supplements for goats fed rice straw in dry season. http://www.lrrd.org/lrrd18/9/ngi18127.htm

[29] Arigbede, O.M. (2007). Performance of WAD goats fed Panicum maximum basal diet with different sources of protein supplements. ASSET Series A (2007) 7 (1) 79-85.

[30] Ajayi, O.A., Adeneye, J.A. and Ajayi, F.T. (2005). Intake and Nutrient utilization of WAD goats fed Mango (Mangifera indica), Ficus (Ficus thionningii), Giliricidia (Gliricidia sepium) foliages and concentrates as supplements to basal diet of Guinea grass (Panicum maximum). World Journal of Agricultural Science 1 (2): 184-189.

[31] Oni, A. O., Arigbede, O. M., Oni, O. O., Onwuka, C. F. I., Anele, U. Y., Oduguwa, B. O. and Yusuf, K. O. (2010). Effects of feeding different levels of dried cassava leaves (Manihot esculenta, Crantz)-based concentrates with Panicum maximum basal on the performance of growing West African Dwarf goats. Livestock Science 129: 24-30. 